\title{
IX Międzynarodowa Konferencja Naukowa pt. Herbart als akademischer Lehrer (Paryż/Francja, 27-28 marca 2017 roku)
}

Odbywające się cyklicznie co dwa lata zjazd i konferencja naukowa Międzynarodowego Towarzystwa Herbarta (MTH) w tym roku miały miejsce jednocześnie w Paryżu. Przygotował je Jean-François Goubet, profesor filozofii w Université d'Artois w Arras (Francja). Obrady trwały w Maison Heinrich Heine stołecznego międzynarodowego kampusu uniwersyteckiego.

Na początku uczestników wydarzenia przywitali przewodnicząca zarządu MTH Rotraud Coriand i główny organizator J.-F. Goubet, który po słowach powitania wygłosił wykład wprowadzający pt. Versuch einer Rekonstruktion der akademischen Lehrzeit Herbarts in Königsberg (Próba rekonstrukcji działalności akademickiej Herbarta w Królewcu). Jego wystąpienie dotyczyło wykładów prowadzonych przez patrona towarzystwa w Uniwersytecie Królewieckim w latach 1809-1833. J.-F. Goubet przenalizował Vorlesungsverzeichnisse, czyli wykazy wykładów, które były drukowane na każdy rok akademicki w formie broszury. Francuskiemu badaczowi udało się odnaleźć wykazy obejmujące okres od 1813 do 1833 roku i je przeanalizować. Na podstawie zgromadzonego materiału J.-F. Goubet ustalił, że program studiów Uniwersytetu w Królewcu różnił się od programu innych ówczesnych uczelni akademickich w Niemczech przedmiotami wprowadzonymi właśnie przez Herbarta, a w szczególności pedagogiką i estetyką, które wykładał on nie jako część filozofii, lecz jako odrębne przedmioty. Poza tym twórca pedagogiki ogólnej opracował i wprowadził do praktyki akademickiej całkowicie nowy przedmiot wprowadzenie do filozofii, do którego napisał również podręcznik pt. Lehrbuch zur Einleitung in die Philosophie (Podręcznik do wprowadzenia do filozofii). Patrząc jednak od strony formalno-administracyjnej, zgodnie zresztą z mianowaniem (niem. Ruf), które otrzymał w 1809 roku od władz uniwersytetu, Herbart nie był uważany w Królewcu za pedagoga, lecz filozofa. W zestawie przedmiotów, których regularnie nauczał, znajdowały się logika i wprowadzenie do filozofii. Oprócz tego nieregularnie wykładał filozofię praktyczną, metafizykę, psychologię i matematykę.

Po krótkiej przerwie poproszona została o wygłoszenie swojego referatu Carole Maigné, profesorka pedagogiki ogólnej w Uniwersytecie w Luzannie (Szwajcaria). 
Tytuł jej wystąpienia brzmiał: Herbart und der ästhetische Formalismus (Herbart a formalizm estetyczny). Referentka uczyniła punktem wyjścia dla swoich rozważań wystawę poświęconą formalizmowi w sztuce pt. Formkunst, która miała miejsce w Wiedniu w roku 2016. Jej organizatorzy wskazywali na Herbarta jako teoretyka nurtu artystycznego zwanego Formkunst, dominującego w XIX-wiecznej monarchii austrowęgierskiej.

Charakteryzując Herbartowską koncepcję estetyki, C. Maigné odwołała się do jego rozprawy habilitacyjnej pt. $A B C$ der Anschauung (Abecadło pogladowości) z 1804 roku. Jej zdaniem zawiera ona cztery elementy, które w późniejszym czasie doprowadziły do wykrystalizowania się oryginalnego stanowiska estetyczno-etycznego. Tymi elementami są: 1) radykalne zerwanie z idealizmem epistemologicznym; 2) uznanie konstytutywnej roli pedagogiki w kształtowaniu podmiotowych form poznawczych; 3) konstruktywistyczna teoria przestrzeni i 4) antykantowska interpretacja tzw. Sichtbarkeit, czyli tego, co widzialne. C. Maigné omówiła szczegółowo każdy z tych elementów, wzbudzając u słuchaczy duże zainteresowanie i szereg pytań, na które odpowiadała podczas dyskusji. Po dyskusji uczestnicy konferencji udali się na obiad.

Po przerwie kontynuowano obrady. Pierwsza sesja tematyczna została zatytułowana Herbart, die Herbartianer und die Philosophie als Universitätsphilosophie (Herbart, herbartyści i filozofia jako dyscyplina uniwersytecka). Moderował ją J.-F. Goubet. Zgromadzeni wysłuchali trzech referatów. Jako pierwszy głos zabrał Faustino Fabbianelli, profesor historii filozofii w Uniwersytecie w Parmie (Włochy). Tytuł jego referatu brzmiał Bildung als synthesis a priori - Giovanni Gentiles Auffassung der Lehrtätigkeit (Kształcenie jako sythesis a priori - rozumienie aktywności nauczyciela według Giovanniego Gentile). Mówca, wychodząc od krytyki Herbartowskiej pedagogiki, którą przeprowadził G. Gentile w niektórych swoich publikacjach, omówił najważniejsze zarzuty sformułowane przez najsłynniejszego włoskiego teoretyka wychowania. Z długiej listy zarzutów F. Fabbianelli szczególną uwagę poświęcił dwom: 1) podporządkowanie pedagogiki etyce i 2) wpajanie cnoty jako główny cel wychowania. Zdaniem gościa z Parmy, G. Gentile trafnie wskazał i ujawnił słabości koncepcji pochodzącego z Oldenburga klasyka pedagogiki i filozofii. Zdaniem niżej podpisanego, G. Gentile nie oddalił się jednak od stereotypowego sposobu odczytywania poglądów Herbarta i nie udało mu się wniknąć głębiej w jego myślenie pedagogiczne i filozoficzne.

Drugą referentką w tej sesji była Leonore Bazinek z Uniwersytetu w Rouen (Francja). Zaprezentowała ona rozważania dotyczące wspomnianego powyżej podręcznika, który opracował Herbart, a mianowicie Das Lehrbuch zur Einleitung in die Philosophie (Podręcznik do wprowadzenia do filozofii). Referentka poszukiwała w nim odpowiedzi na następujące pytania: 1) jak Herbart uzasadnia konieczność wyodrębnienia wprowadzenia do filozofii jako autonomicznego przedmiotu nauczania akademickiego; 2) jakie stawia cele temu przedmiotowi i 3) jaką funkcję ma on do spełnienia z perspektywy nauki o państwie (niem. Staatslehre), która 
z jednej strony jest ostatnim obszarem tematycznym w tym podręczniku, a z drugiej stanowi zwieńczenie herbartowskiej filozofii praktycznej i metafizyki.

W ostatnim referacie tego dnia wystąpił David Romand z paryskiego Uniwersytetu Diderota, który zaprezentował temat: Joseph Wilhelm Nahlowsky (1812-1885) and the "affective turn” of Herbartianism (Joseph Wilhelm Nahlowsky [1812-1885] i „afektywny przełom” herbartyzmu). Mówca przybliżył zgromadzonym postać i dzieło jednego z przedstawicieli herbartyzmu - Josepha Wilhelma Nahlowsky’ego, który urodził się w Pradze, gdzie uzyskał humanistyczne wykształcenie. Jako nauczyciel przeniósł się do Wiednia i rozwinął tam swoją działalność naukową i pedagogiczną. Spośród dziedzin uprawianych przez Herbarta najbardziej interesowały J. W. Nahlowsky’ego estetyka i psychologia. Wniósł znaczący wkład w postęp tej ostatniej, reinterpretując poglądy mistrza w odniesieniu do dziedziny uczuć, którą wówczas odkrywała dopiero psychologia.

Po dyskusji ogłoszona została przerwa, a po niej odbyło się walne zebranie MTH. Jednym z punktów programu były wybory zarządu. Z powodów rodzinnych z pełnienia funkcji przewodniczącej zrezygnowała R. Coriand. Na stanowisko przewodniczącego został wybrany Rainer Bolle (Karlsruhe/Niemcy). Członkami zarządu zostali: Jean-François Goubet (Arras/Francja), Katja Grundig de Vazquez (Essen/ Niemcy), Alexandra Schotte (Augsburg/Niemcy), Klaus Klattenhoff (Oldenburg/ Niemcy).

Na drugi dzień konferencji zaplanowano dwie sesje tematyczne i workshop. Pierwszą sesję poprowadził nowy przewodniczący zarządu MTH Rainer Bolle. Została ona podzielona na dwie części, które nosiły ten sam tytuł co sesja z poprzedniego dnia.

Na początku pierwszej części prowadzący obrady udzielił głosu Xiaolian Luo, doktorantce z Uniwersytetu w Pekinie (Chiny), która odbywa staż naukowy w Uniwersytecie Humboldtów w Berlinie (Niemcy). Tytuł jej wystąpienia brzmiał: Die Rolle der Herbartischen Pädagogik bei der Mitgestaltung der Pädagogik als ein akademisches Fach in China (1901-1912) (Rola pedagogiki herbartowskiej w budowaniu pedagogiki jako dyscypliny akademickiej w Chinach [1901-1912]). Referentka podzieliła swoje wystąpienie na trzy części: 1) prezentacja kontekstu kulturowego Chin; 2) proces krystalizowania się pedagogiki jako samodzielnej dyscypliny naukowej i 3) znaczenie koncepcji Herbarta dla rozwoju pedagogiki akademickiej w Państwie Środka. Uczestnicy spotkania zostali zapoznani ze złożonym, ale jednocześnie bardzo interesującym procesem adaptacji zasad pedagogiki herbartowskiej w Chinach, który został zapoczątkowany w drugiej połowie XIX wieku przez teoretyków wychowania z Japonii. X. Luo przedstawiła w szczegółach dorobek z lat 1901-1912. Okres ten uznała za szczytową fazę rozwoju „chińskiego herbartyzmu”.

Marcel Hauer z Uniwersytetu w Bambergu (Niemcy) był drugim referentem w tej sesji tematycznej. Przedstawił temat Die Etablierung des Herbartianismus als Universitätspädagogik in den USA - am Beispiel der Illinois Normal University (Instytucjonalizacja herbartyzmu $w$ USA jako pedagogiki uniwersyteckiej na 
przykładzie Illinois Normal University). Jak wyjaśnił prelegent, wybór Illinois Normal University w Chicago nie jest przypadkowy. Ten uniwersytet stał się bowiem w ostatnich dwóch dekadach XIX wieku głównym ośrodkiem propagowania idei pedagogicznych Herbarta w USA i jednocześnie wyszła z niego inicjatywa Johna Dewey'a reformy wychowania, znana jako Nowe Wychowanie.

Po dyskusji dotyczącej wysłuchanych referatów uczestnicy zostali zaproszeni na przerwę kawową. Po niej rozpoczęła się druga część drugiej sesji. Zgromadzeni wysłuchali dwóch referatów. Pierwszy głos zabrał András Németh z Uniwersytetu w Budapeszcie (Węgry). Zaprezentował on referat pt. Die Rolle der Herbartianer in der ungarischen Universitätspädagogik (Rola herbartystów w tworzeniu węgierskiej pedagogiki akademickiej). Na początku prelegent przypomniał słuchaczom swoje wystąpienie sprzed dwóch lat, w którym nakreślił dzieje węgierskiego herbartyzmu. Jako cel tego wystąpienia wskazał spojrzenie na historię recepcji idei Herbarta w Europie Środkowo-Wschodniej. W odniesieniu do tego A Németh przedstawił historiozoficzny szkic rozwoju tego regionu, ze szczególnym uwzględnieniem XIX wieku, kiedy to herbartyzm wyznaczał kanony profesjonalizacji i instytucjonalizacji oświaty publicznej w takich krajach, jak obecne Węgry, Czechy, Słowacja i Polska. Zdaniem znawcy historii pedagogiki, dziejowa rola, jaką odegrał herbartyzm w drugiej połowie XIX wieku w tej części Europy, wynikała z przypisywanego mu potencjału w zakresie modernizacji tradycyjnego wychowania i kształcenia.

Drugą prelegentką była Katja Grundig de Vazquez z Uniwersytetu DuisburgEssen (Niemcy), która przedstawiła temat: Pädagogik als Wissenschaft - Anmerkungen zu grundlegenden Bausteinen der republikanischen Bildungsreform der Dritten Französischen Republik und ihrer theoretischen Fundierung (Pedagogika jako nauka. Uwagi na temat podstawowych elementów reformy edukacji w okresie Trzeciej Republiki we Francji i ich ugruntowania teoretycznego). Młoda badaczka z Essen przyznała, że co prawda we Francji nie ukształtowała się osobna linia herbartyzmu, jednak rozwój systemu kształcenia powszechnego świadczy o tym, że można mówić o oddziaływaniu idei Herbarta. W swoim wystąpieniu referentka przestawiła wstępną rekonstrukcję tego oddziaływania. Zwróciła uwagę słuchaczy na dwie tendencje: 1) emancypację pedagogiki jako autonomicznego przedmiotu akademickiego i 2) instytucjonalizację kształcenia nauczycieli na poziomie akademickim.

Zgodnie z dotychczasowym zwyczajem po referatach odbyła się dyskusja. Po niej uczestnicy konferencji udali się na obiad. Po przerwie przeprowadzono workshop. Tym mianem określa się wprowadzoną przed dwoma laty formę wymiany myśli na temat działań podejmowanych przez członków MTH, które nie są bezpośrednio związane z tematem konferencji.

W czasie tegorocznego workshop głos zabrali András Németh i Beatrix Vincze z Uniwersytetu w Budapeszcie (Węgry). Pierwszy z węgierskich naukowców zaprezentował swoje zamierzenie badawcze, które polegają na rekonstrukcji historii pedagogiki Herbarta w krajach Europy Środkowo-Wschodniej, o których była już 
mowa powyżej. B. Vincze przedstawiła postać wybitnego węgierskiego pisarza Lászlo Németha, który opracował teoretycznie zasady wychowania społecznego i nawet starał się je wcielić w życie. Zamierzenie badawcze B. Vincze polegają na odczytaniu idei pedagogicznych L. Németha na tle poglądów Herbarta.

Po krótkiej przerwie, która nastąpiła po workshop, rozpoczęła się trzecia i ostatnia sesja tegorocznej konferencji. Zatytułowano ją Herbart und Herbartianer als Universitätslehrer (Herbart i herbartyści jako nauczyciele akademiccy). Prowadzenie zostało powierzone Klausowi Klattenhoffowi.

Pierwszy z dwóch referatów w tej sesji wygłosiła Alexandra Schotte z Uniwersytetu w Augsburgu (Niemcy). Podjęła ona temat "Wirken so lange es noch Tag ist!” Herbart als akademischer Lehrer im Lichte von Briefkorrespondenzen aus den Jahren 1831-1841 („Róbmy, dopóki trwa jeszcze dzień!” - Herbart jako nauczyciel akademicki $w$ świetle korespondencji $z$ lat 1831-1841). Referentka przeanalizowała listy pisane przez Herbarta i te, które otrzymywał, pochodzące z końcowej fazy jego działalności w Królewcu i z drugiego pobytu w Getyndze (1833-1841). Swoje rozważania przedstawiła w trzech punktach: 1) etapy gromadzenia i publikowania korespondencji Herbarta w ramach jego spuścizny piśmienniczej; 2) krąg osób, z którymi utrzymywał kontakt listowny i 3) główne wątki tematyczne korespondencji.

Jako ostatni wystąpił niżej podpisany z referatem pt. Herbart über ars studendi (Herbart o sztuce studiowania). Przedmiotem rozważań były poglądy Herbarta odnośnie do umiejętności studiowania. Autor usytuował swoje rozważania w kontekście szeroko dyskutowanej współcześnie kwestii celów studiów akademickich i znaczenia wiedzy naukowej w kształtowaniu osobowości. Stanowisko Herbarta zostało zaprezentowane w nawiązaniu do dwóch modeli relacji między nauką a kształceniem (niem. Bildung), których autorami są Wilhelm von Humboldt i Max Weber. Herbart przedstawił je w jednym ze swoich wczesnych opracowań pt. Über philosophisches Studium (O studiowaniu filozofi) z 1807 roku. Referent omówił trzy problemy: 1) miejsce koncepcji Herbarta w historii problemowej kształcenia akademickiego; 2) czym jest studiowanie według Herbarta i 3) czemu ma służyć studiowanie. Również po tych wystąpieniach odbyła się dyskusja, a po niej nastąpiło uroczyste zakończenie konferencji. Zamykając obrady, przewodniczący MTH Rainer Bolle podziękował uczestnikom za przybycie, organizatorom za gościnne przyjęcie i zaprosił wszystkich na kolejny zjazd za dwa lata. 